\title{
Preparation of porous poly (lactic acid) fibers by medium field electrospinning for tissue engineering applications
}

\author{
André Luiz dos Santos** (D), Marcia A. Tomaz Duarte ${ }^{a}$, Sérgio H. Pezzin ${ }^{\mathrm{b}}$, Leandro Silva ${ }^{\mathrm{c}}$, \\ Juliana A. Domingues ${ }^{d}$ \\ ${ }^{a}$ Sociedade Educacional de Santa Catarina, Departamento de Pós-Graduação em Engenharia \\ Mecânica, Joinville, SC, Brasil \\ ${ }^{b}$ Universidade do Estado de Santa Catarina, Departamento de Química, Centro de Ciências \\ Tecnológicas, SC, Brasil \\ 'Sociedade Educacional de Santa Catarina, Departamento de Engenharia Elétrica, Joinville, SC, Brasil \\ ${ }^{d}$ Universidade Estadual de Campinas, Departamento de Biologia Celular e Estrutural, Campinas, SP, Brasil
}

Received: August 15, 2019; Revised: March 12, 2020; Accepted: May 01, 2020.

Electrospun fibers find a number of biomedical applications, like scaffolds for tissue engineering, as polymer nanofiber mats can mimic the extracellular matrix (ECM) of the body. In this research, non-woven mats composed of poly(L-lactic acid) (PLLA) fibers were obtained by low voltage $(6 \mathrm{kV})$ electrospinning of PLLA/chloroform (CL)/sodium lauryl ether sulfate (SLES) solution. Tests were performed in two different collector/capillary distances and the produced fibers were evaluated by scanning electron microscopy (SEM), differential scanning calorimetry (DSC) and cell viability. The results show the formation of three dimensional mats composed of porous fibers created by the addition of small amounts of aqueous solution of SLES surfactant; a higher crystallinity degree for longer collector/ capillary electrospun distance and positive cell proliferation.

Keywords: Eletrospinning, Medium field, Tissue engineering, PLLA.

\section{Introduction}

Electrospinning is a process by which submicron fibers can be produced ${ }^{1,2}$, from polymer solution or melt, by electrostatic forces. These non-woven nanofiber mats have a wide variety of applications, including semi-permeable membranes, and other structures used in tissue engineering ${ }^{3-5}$. These fibers are generally obtained by using a high voltage source $(10-20 \mathrm{kV})$ direct current (DC), with the formation of a polymer jet between a needle and a collector separated by a distance of the order of $10-15 \mathrm{~cm}$. This conventional method of electrospinning, producing randomly oriented mats of nanofibers, is also known as Far Field Electrospinning (FFES) $)^{1,6-10}$.

Greater control over the fibers can be achieved using a modified electrospinning technique, known as Near Field Electrospinning (NFES), which uses an electrode collector distance from $500 \mu \mathrm{m}$ to $3 \mathrm{~mm}$, in order to take advantage of only the stable jet stage. It is a production method of oriented nanofibers, with standardized deposition ${ }^{11,12}$.

One of the most promising application of the nanofibers is in the biomedical field. This membranes can be used as wound dressings and appropriate medium for tissue regeneration like scaffolds for tissue engineering. Due to physical structural similarities to the ECM, with high porosity and large surface area, they provide appropriate drainage and air permeability, comfort in its application and removal, and allow drug-loading and controlled release $\mathrm{e}^{13,14}$.

*e-mail: andrelusantos11@gmail.com
For this type of application, a mechanically stable three-dimensional matrix, with interconnected pores, is required, so that the cells can grow throughout the structure. As the cells grow and organize, the polymer degrades and is absorbed by the body, leading to a natural tissue replacement ${ }^{15-17}$

This could bring value for people with epithelial injury, preventing bacterial infection even at hospitals with rapid and effective coverage of the wound. Also promoting skin transplants, wich present drawbacks as few donors, the risk of rejection of the implanted material, and the time necessary for complete healing ${ }^{18-20}$.

Additionaly, porous features can improve the functionality of the fibers, by increasing surface area, facilitating the cell attachment. Among the mechanisms to explain pore generation in polymer membranes is Phase Separation (PS), where the incorporation of a poor or non-solvent can induce PS and lead to porosity, allowing the formation of circular pores after posterior non-solvent evaporation. This is a simple method, known as non-solvent induced phase separation (NIPS) ${ }^{4}$.

Biodegradable polymers have several potential applications in the biomedical field due to its biocompatibility and biodegradability ${ }^{21}$. Among these, the PLLA is a bioresorbable and biocompatible polymer that have been extensively studied for biomedical applications, including scaffolds for epithelial cell regeneration ${ }^{22-25}$. PLLA is a semicrystalline polymer with a glass transition temperature of about $57^{\circ} \mathrm{C}$, melting point of $174-184{ }^{\circ} \mathrm{C}$; which can be made of $100 \%$ 
renewable sources and degrades under natural conditions. It has mechanical properties compatible with the applications in the medical field, with elastic modulus of 3.2 to $3.7 \mathrm{GPa}^{26-28}$.

The crystallinty is an important characteristic when considering the material for biomedical applications. The high elongation strains and shear stresses applied on polymer chains during electrospinning are reported to cause alignment of the macromolecular chains along the fibre axis, leading to high degree of molecular orientation. One of the possible influences is related to the effect of crystallinity on the degradation kinetics ${ }^{29,30}$.

No studies specifically reporting the use of SLES surfactant on electrophilic polymer solutions were found in the literature; however, in general, surfactants have been used in a variety of ways due to their ability to lower the surface/interfacial tension of the medium in which they are dissolved ${ }^{31}$. They are also cited as a mean to avoid the formation of grains, as they decrease the surface tension of the solution and help to increase the interaction between the solvent and the polymer chains, avoiding the occurrence of beads on the surface of the fibers ${ }^{32}$.

This work aims to obtain PLLA membranes composed of PLLA sub-micro fibers by low voltage electrospinning $(6 \mathrm{kV})$ and validate its use as a scaffold for tissue engineering.

\section{Materials and Methods}

\subsection{Electrospinning apparatus}

The apparatus is composed of an infusion pump SDA 1800 (SDAMed), working with a $10 \mathrm{ml}$ syringe and a metal needle with $0.7 \mathrm{~mm}$ in diameter by $25 \mathrm{~mm}$ length; a high voltage power supply (Leybold), in the 0 to $6 \mathrm{kV}$ range; and a collector, comprising a rotating aluminum cylinder driven by an electric motor, which is powered by a low voltage supply (Minipa PS-500, 0-30V) allowing the collector speed control. The whole apparatus was used in a closed room at ambient temperature.

\subsection{Materials}

The polymer used in this work was poly (L-lactic acid), PLLA, synthesized at the Faculty of Medical Sciences, Pontifical Catholic University of São Paulo (PUC/Sorocaba), with an weight average molecular mass of $2.78 \times 10^{5} \mathrm{~g}^{\mathrm{m}} \mathrm{mol}^{-1}$ and polydispersity of 1.58. Chloroform $\left(\mathrm{CHCl}_{3}, \mathrm{PAACS}\right)$ was purchased from Vetec (Brazil), while aqueous solution of sodium lauryl ether sulfate (SLES) $25 \mathrm{wt} \%$, was supplied by Metaquímica (Brazil).

\subsection{Electrospinning of PLLA}

$8 \mathrm{wt} \%$ PLLA solutions were prepared in chloroform at room temperature $\left(25 \pm 2{ }^{\circ} \mathrm{C}\right)$. For some experiments, $50 \mu \mathrm{L}$ of the $25 \mathrm{wt} \%$ SLES aqueous solution were added to $33 \mathrm{~mL}$ of the PLLA solution. To the complete homogenization, the solutions were stirred at $30 \mathrm{rpm}$, using a magnetic bar, for at least 1 hour.

Then, the PLLA solution was placed in a $10 \mathrm{~mL}$ syringe at the infusion pump. After preliminary tests to set appropriate parameters for the preparation of fiber mats, the electrical voltage applied to the needle was $6 \mathrm{kV}$, while the flow rate and the collector speed were fixed at $0.5 \mathrm{~mL} \cdot \mathrm{h}^{-1}$ and $540 \mathrm{rpm}$, respectively. The two tests were conducted varying the needle to collector distances from $2.0 \mathrm{~cm}$ (test 2) to $4.0 \mathrm{~cm}$ (test 1). All the experiments were carried out at $25 \pm 2{ }^{\circ} \mathrm{C}$.

\subsection{Scanning Electron Microscopy}

The morphology and diameter of the collected fibers were investigated by scanning electron microscopy (Jeol JSM-6701F), at $10 \mathrm{kV}$. The fiber mats were coated with gold during $3 \mathrm{mim}$ at $20 \mathrm{~mA}$, using a Denton Vacuum Sputer Coater. The fiber diameters were measured with an image analyzer (ImageJ, v. 1.49p). For each sample, average fiber diameter and standard deviation were determined from 80 measurements of random fibers.

\subsection{Differential Scanning Calorimetry-DSC}

DSC measurements were performed in a TA Instruments Q20 equipment to the determination of the glass transition $\left(\mathrm{T}_{\mathrm{g}}\right)$, cold-crystallization $\left(\mathrm{T}_{\mathrm{cc}}\right)$ and melting $\left(\mathrm{T}_{\mathrm{m}}\right)$ temperatures and the crystallinity degrees of PLLA bulk samples and fiber mats. Samples, with ca. $10 \mathrm{mg}$, were heated from 30 to $200^{\circ} \mathrm{C}$ at a heating rate of $10{ }^{\circ} \mathrm{C} \cdot \mathrm{min}^{-1}$ under nitrogen atmosphere. The calibration of the DSC was carried out with a standard sample of indium. The glass transition was calculated as the midpoint of the jump in heat capacity (ISO 11357-2). The crystallization (exothermal) and melting (endothermal) were characterized by the onset and peak temperatures, as well as by the area under the corresponding peaks. The crystallinity degree, X (\%), was calculated according to the following equation:

$$
\mathrm{X}(\%)=\left[\Delta \mathrm{H}_{\mathrm{m}}-\Delta \mathrm{H}_{\mathrm{c}}\right] /\left[\Delta \mathrm{H}_{\mathrm{m}}{ }^{\mathrm{o}}\right] \times 100
$$

Where $\Delta \mathrm{H}_{\mathrm{m}}$ and $\Delta \mathrm{H}_{\mathrm{c}}$ are the melting and the crystallization enthalpies respectively, and $\Delta \mathrm{H}_{\mathrm{m}}{ }^{\circ}$ is the reference $\Delta \mathrm{H}_{\mathrm{m}}\left(93.7 \mathrm{J.g}^{-1}\right)$ of $100 \%$ crystalline PLA. The summarized values were calculated by the average of two determinations.

\subsection{Cell viability}

In the cell viability investigation, the PLLA electrospun mats from tests at 2.0 and $4.0 \mathrm{~cm}$ have been previously sterilized by UV germicidal irradiation for $30 \mathrm{~min}$ and acclimated in DMEM (Dulbecco's Modified Eagle's Medium) culture for 24 hours. ASC (Human Adipose Stem Cells - Catalog number R7788115, ThermoFisher) were seeded over the electrospun mats at a concentration of 5 $\mathrm{x} 10^{4}$ cells / $\mathrm{mL}$ and maintained in DMEM supplemented with penicillin-streptomycin and $10 \%$ fetal bovine serum (FBS) after 1, 5 and 10 days of culture. Cellular constructs were incubated at $37^{\circ}$ with $0,5 \mathrm{mg} / \mathrm{mL}$ MTT (3-(4,5Dimethylthiazol-2-yl)-2,5-Diphenyl tetrazolium Bromide) for $4 \mathrm{~h}$. Dimethyl sulfoxide (DMSO) was added to solubilize the MTT-formazan product. Cell viability was quantified by measurement of optical density at $570 \mathrm{~nm}$, using a microplate reader Elx-800-UV (Bio-Tek Instruments, USA. The data were analyzed by non-parametric multiple comparison test Tukey's test with one-way ANOVA. 


\section{Results and Discussions}

\subsection{SEM}

From the SEM images shown in Figure 1 and 2, it is evidenced the production of uniform, three dimensional mats composed by randomly oriented fibers, so as a homogeneous formation of interstitial spaces between the fibers. Mats produced using a needle-to-collector distance of $2.0 \mathrm{~cm}$ (Figure 2) show a more interconnected fiber morphology, than sample produced at $4.0 \mathrm{~cm}$ (Figure 1). In both cases, no substantial formation of beads were observed.

Figure 3 emphasizes the porosity found in the electrospun PLLA fibers. It is noted no bead formation, but a great variation of fiber diameters, with the presence of crosslinking fibers (Figure 3b).

The observed fiber porosity is attributed mainly to the addition of a small amount of a surfactant (SLES), in aqueous solution, to the PLLA/CL system. The presence of SLES reduces the surface tension of the solution and helps to increase the interaction between the solvent and the PLLA chains, which prevents the formation of beads on the surface of the fibers, as well as avoid the locking of the syringe.
This alternative was suggested by Pezzin et al. ${ }^{33}$, who studied the preparation of polyhydroxybutyrate (PHB) membranes by electrospinning and observed that the addition of sodium dodecyl sulfate (SDS) to a $10 \%(\mathrm{w} / \mathrm{v})$ PHB solution in chloroform/dimethylformamide (9/1) was important to maintain a constant flow of the solution and increase reproducibility.

Moreover, the little bit of water (ca. $0.1 \mathrm{wt} \%$ ) added to the PLLA/CL solution together with the surfactant is regarded as the key to the formation of pores during the electrospinning process (NIPS mechanism)

The fiber diameter distribution for a typical mat sample is shown in Figure 4. Most of the fibers (ca. 60\%) have diameters between 1.0 and $2.5 \mu \mathrm{m}$, while $27.5 \%$ are nanofibers with diameters between 90 and $400 \mathrm{~nm}$.

\subsection{DSC}

The Table 1 summarizes the values for $\mathrm{T}_{\mathrm{g}}, \mathrm{T}_{\mathrm{m}}, \Delta \mathrm{H}_{\mathrm{m}}, \Delta \mathrm{H}_{\mathrm{cc}}$ and crystallinity degree obtained by DSC for PLLA bulk samples and fiber mats.
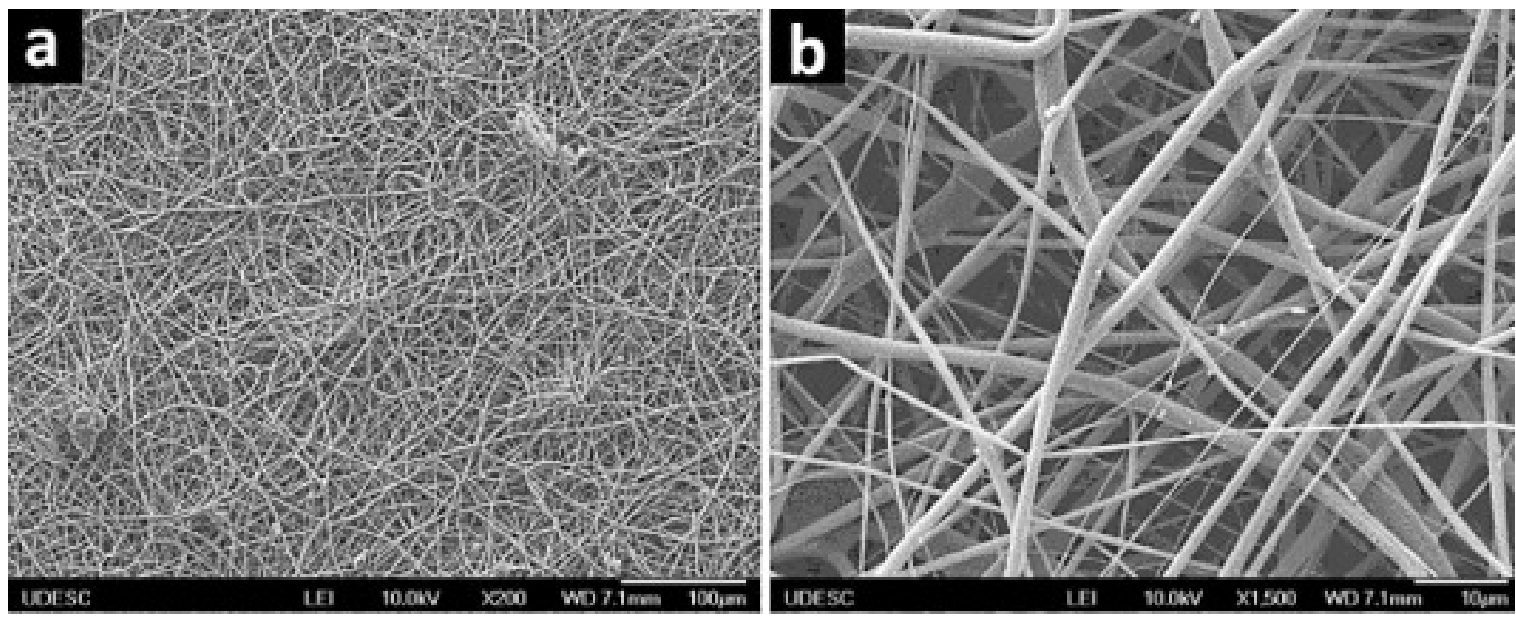

Figure 1. SEM micrographs of test 1: a) fiber mat $(200 \mathrm{X}, \mathrm{b})$ a closer look $(1500 \mathrm{X})$ at the fiber surface. Electrospinning parameters: voltage $=6 \mathrm{kV}$; needle-to-collector distance $=4.0 \mathrm{~cm} ; 8 \mathrm{wt} \%$ solution PLLA in chloroform with $0.038 \mathrm{wt} \%$ of SLES, T $=25 \pm 2{ }^{\circ} \mathrm{C}$.
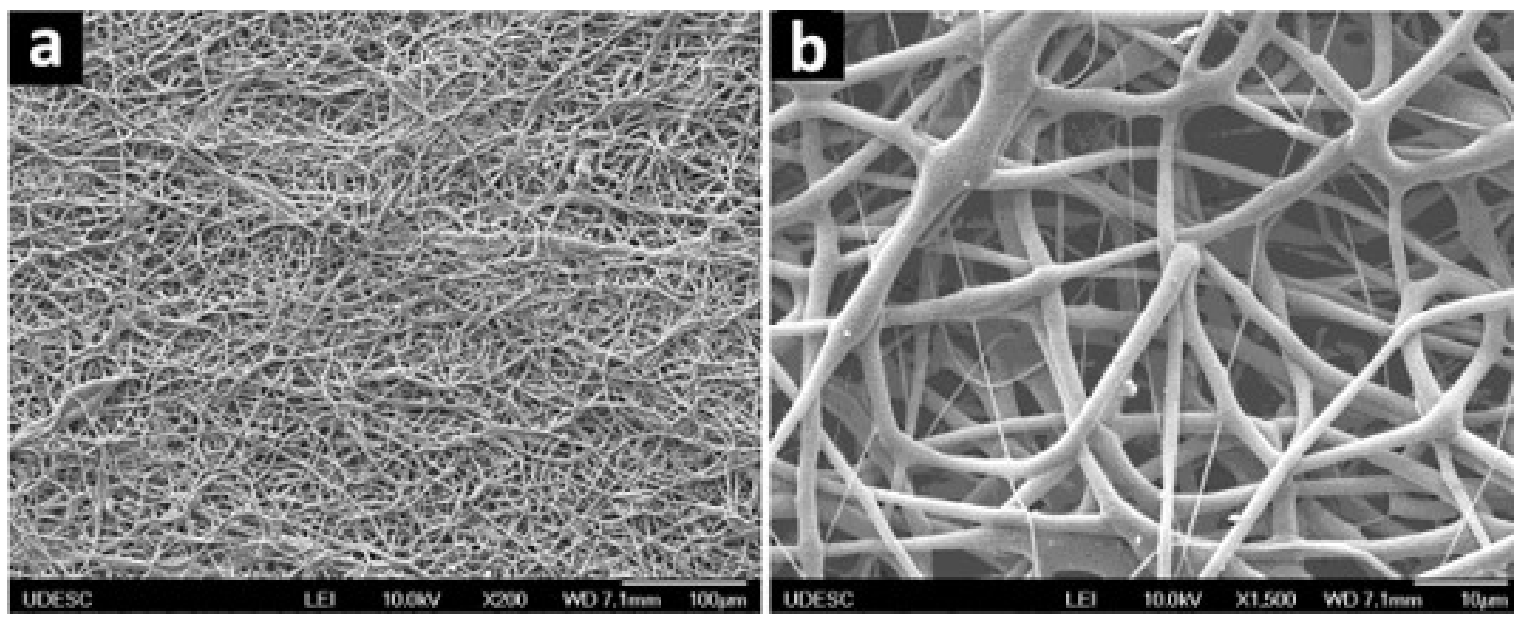

Figure 2. SEM micrographs of test 2: a) fiber mat $(200 \mathrm{X})$, b) a closer look $(1500 \mathrm{X})$ at the fiber surface. Electrospinning parameters: voltage $=6 \mathrm{kV}$; needle-to-collector distance $=2.0 \mathrm{~cm} ; 8 \mathrm{wt} \%$ solution PLLA in chloroform with $0.038 \mathrm{wt} \%$ of SLES, T $=25 \pm 2{ }^{\circ} \mathrm{C}$. 

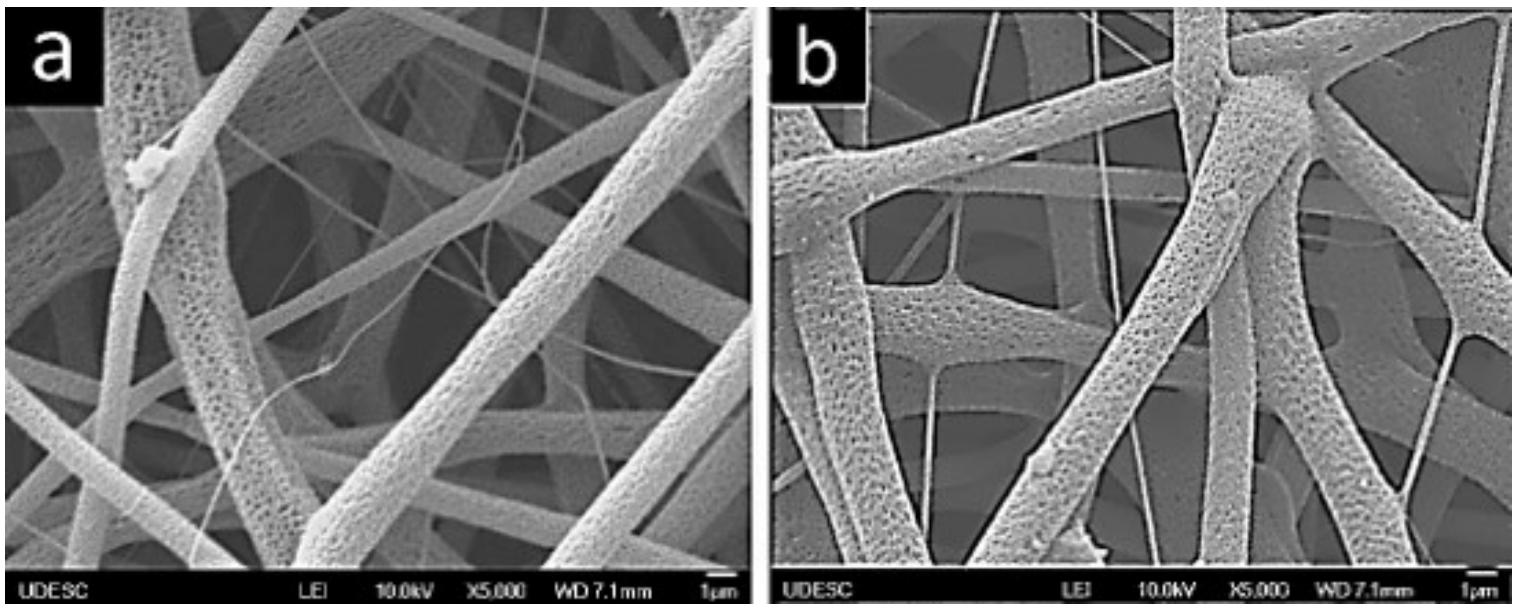

Figure 3. SEM micrographs emphasizing fiber surface porosity. a) test 1 (needle-to-collector distance $=4.0 \mathrm{~cm}$ ) and b) test 2 (needle-to-collector distance $2.0 \mathrm{~cm}$ ).
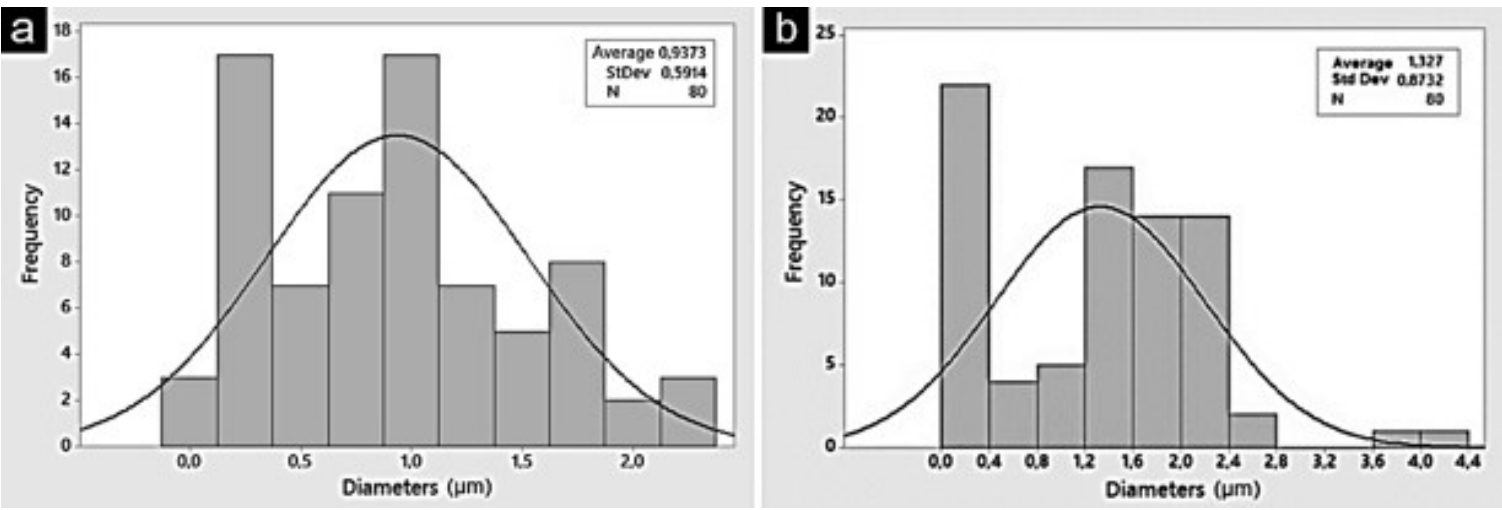

Figure 4. Fiber diameter distribution of as-spun PLLA fibers, a) test 1 (needle-to-collector distance $=4.0 \mathrm{~cm}$ ) and $\mathrm{b}$ ) test 2 (needle-to-collector distance $2.0 \mathrm{~cm})$.

Table 1. DSC parameters for PLLA bulk samples and fiber mats produced at different needle-to-collector distances: Tg - glass transition temperature at the transition mid-point; $\mathrm{Tm}$ - melting temperature; $\Delta \mathrm{Hm}$ - enthalpy of melting; $\Delta \mathrm{Hc}$ - enthalpy of crystallization

\begin{tabular}{lccccc}
\hline \multicolumn{1}{c}{ Sample } & $\mathrm{T}_{\mathrm{g}}\left({ }^{\circ} \mathrm{C}\right)$ & $\mathrm{T}_{\mathrm{m}}\left({ }^{\circ} \mathrm{C}\right)$ & $\begin{array}{c}\Delta \mathrm{H}_{\mathrm{m}} \\
(\mathrm{J} / \mathrm{g})\end{array}$ & $\begin{array}{c}\Delta \mathrm{H}_{\mathrm{c}} \\
(\mathrm{J} / \mathrm{g})\end{array}$ & $\begin{array}{c}\text { Crystallinity Degree } \\
(\%)\end{array}$ \\
\hline Bulk powder & 63 & 180 & 32 & 20 & 37 \\
\hline Fiber mat $-4.0 \mathrm{~cm}$ & 61 & 175 & 54 & 16 & 40 \\
\hline Fiber mat $-2.0 \mathrm{~cm}$ & 63 & 174 & 37 & 15 & 23 \\
\hline
\end{tabular}

The $\mathrm{T}_{\mathrm{g}}$ and $\mathrm{T}_{\mathrm{m}}$ values for PLLA as powder or fiber mats does not differ significantly, and are in agreement with the literature $^{26-28 .}$ On the other hand, the crystallinity degree is higher for the fiber mats $(40 \%)$ at the $4.0 \mathrm{~cm}$ test, than for the powder form $(37 \%)$. This is due to the elongation of the solution, during the electric field application, in the form of fine fibers, causing the polymer chains to elongate parallel to the jet direction. The polymer chains extend in the direction of the forming filament, giving rise to the fibers. It is also verified that the needle-to-collector distance considerably affects the crystallinity degree. Fibers obtained at a distance of $2.0 \mathrm{~cm}$ are $16 \%$ less crystalline than those produced at $4.0 \mathrm{~cm}$.

In fact, the degree of crystallinity of a polymer depends on its cooling rate during the solidification process. During crystallization, the highly randomly oriented and entangled chains in the solution need to assume an orderly configuration. For this to occur, sufficient time must be given for the chains to move and align in relation to each other.

Thus, it is estimated that the distance (collector/capillary) of $2.0 \mathrm{~cm}$ featuring a shorter time for fiber formation and solvent evaporation provided a less crystalline fiber than those produced at $4.0 \mathrm{~cm}$, wich has a greater distance, allowing a longer time to the alignment of the polymer chains and, thereby, featuring a higher degree of crystallinity. For a better understanding, the respectives DSC graphs are shown in the Figure 5. 

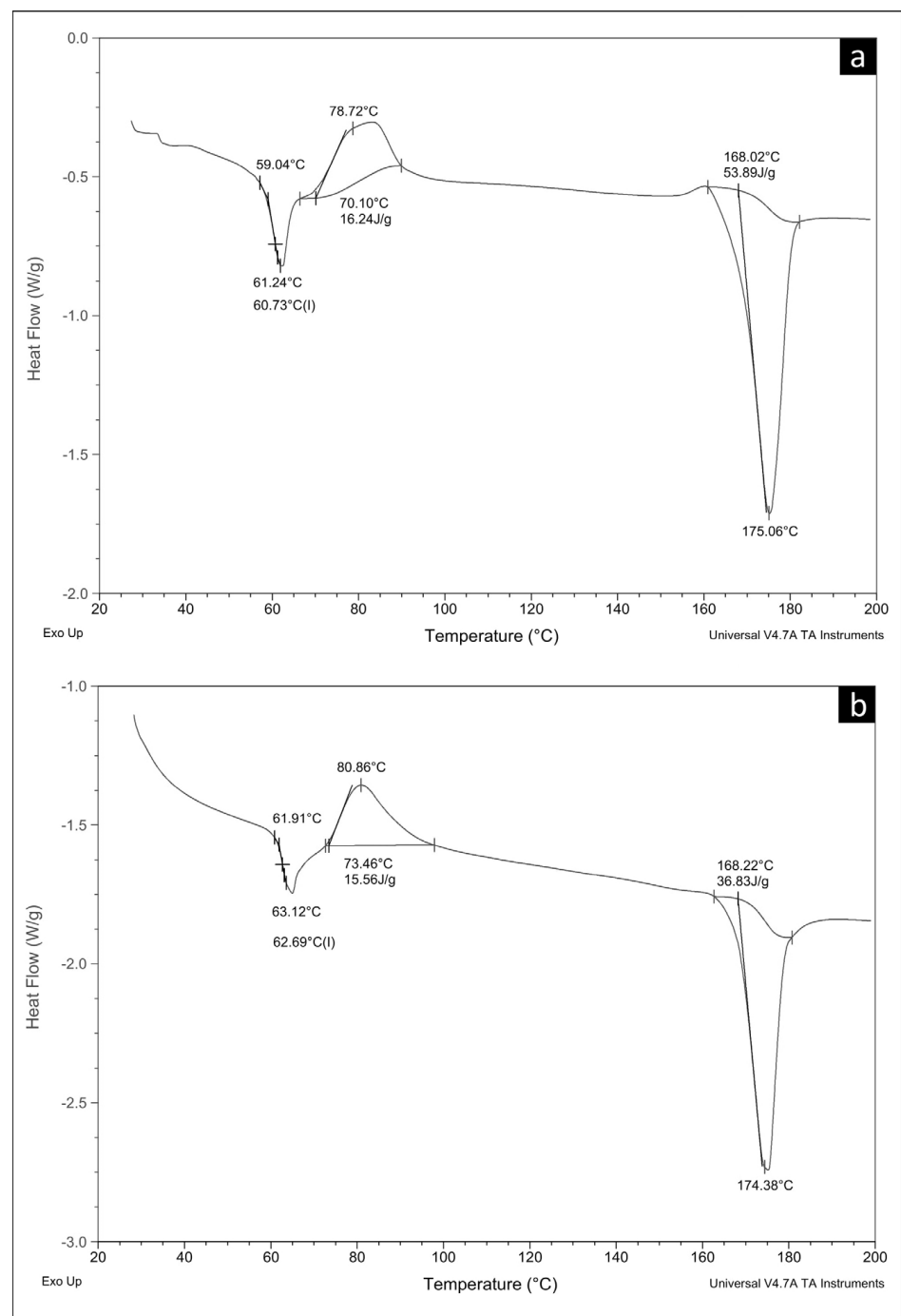

Figure 5. DSC curves for: a) test 1 (needle-to-collector distance $=4.0 \mathrm{~cm}$ ) and b) test 2 (needle-to-collector distance $2.0 \mathrm{~cm}$ ).

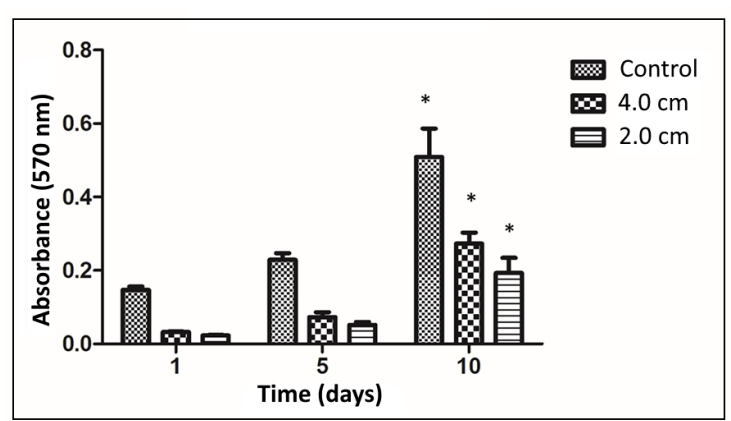

Figure 6. Cell viability graph.

\subsection{Cell viability}

In Figure 6 it is shown the graph characterizing the cell viability. In this assay, cell growth was noted after 10 days of cultivation. The polystyrene plate was used as control. Values are expressed as mean $\pm \mathrm{SD}, \mathrm{n}=5$. ${ }^{*} \mathrm{P}<0.01$.
Both mats allowed the proliferation of ASC's, with a higher viability value for the $4 \mathrm{~cm}$ test. There was significant cell growth $(\mathrm{p}<0.01)$ in both control group as in the mats, when compared the 10 days assay with the others. Thus, there was obtained a positive result considering the main purpose of application of this technique, i.e. to allow cell proliferation in the polymer framework.

One reason for the effective growth of cells produced in the membrane, may be the porosity on the surface of the fibers. In fact, porous fibers have been studied in various fields due to a large surface area and high porosity ${ }^{16,22}$. Furthermore, the type of roughness of these fibers determine the number and types of anchorage of the cells with its substrate. It is observed that on rough surfaces, the cells form layers covering the valleys between the peaks of these pores ${ }^{34}$.

According to literature ${ }^{14}$ nonwoven polymer nanofiber are among the most promising biomaterials analogs as extracellular matrix, for applications such as scaffold for cell growth. Theoretically, these mats are ideal, because the cells are sensitive to the topography of the support surface, 
although the exact reasons for this are yet not clear. Thus the search for surfaces with beneficial influences on cell growth has been the subject of recent research ${ }^{35}$.

\section{Conclusions}

A three-dimensional fiber network with highly porous surface, was obtained by MFES. Interconnected pores and thinner diameters were obtained using a greater collector/capillary distance $(4.0 \mathrm{~cm})$.

The PLLA, proved to be viable to the scaffold application, due to its biocompatibility with the type of implanted cell. It was also verified that the presence of a small amount of water, acting as a nonsolvent which evaporates during the electrospinning process, favors the formation of fibers with high surface porosity, adequate for cell attachment, proliferation, and diferentation which is ideal for cell growth.

The theory of the cristalinity increase through the electrospinning process was confirmed, with fiber mats presenting a higher cristalinity degree than the bulk powder test as well as a higher degree when using a greater collector/capillary distance.

Another important observation is about the electrospinning process, which can be assumed as a novel medium field electrospinning technique, (MFES), once it is not in the range of the FFES $(10-15 \mathrm{~cm}$ and $10-20 \mathrm{kV})$ nor in the range of NFES $(500 \mu \mathrm{m}-3 \mathrm{~mm})$, by using intermediate needle-to-collector distances $(2-4 \mathrm{~cm})$ and potential $(6 \mathrm{kV})$ to the production o PLLA fiber mats.

The use of this relatively low voltage, medium electrical field, and rotating collector was not able to align the fibers; thus, it can be conclude that even with the reduced voltage and collector/capillary distance, the fibers were collected in its unstable fase, resulting in a aleatory deposition.

In order to provide a scaffold with the most suitable proprerties to the tissue engineering application, the material should mimic the ECM as much as possible, thus the obtained fiber mats are potentially useful for tissue regeneration applications.

\section{Acknowledgements}

The authors thank UDESC-Joinville and PUC-Sorocaba for supplying materials and equipment.

\section{References}

1. Doshi J, Reneker DH. Electrospinning process and applications of electrospun fibers. J Electrost. 1993;3:1698-703.

2. Xin Y, Reneker DH. Garland formation process in electrospinning. Polymer (Guildf). 2012;53:3629-35.

3. Bhardwaj N, Kundu SC. Electrospinning: A fascinating fiber fabrication technique. Biotechnol Adv. 2010;28:325-47.

4. Huang C, Thomas NL. Fabricating porous poly(lactic acid) fibres via electrospinning. Eur Polym J. 2018;99:464-76.

5. Deitzel JM, Kleinmeyer JD, Hirvonen JK, Beck Tan NC. Controlled deposition of electrospun poly(ethylene oxide) fibers. Polymer (Guildf). 2001;42:8163-70.

6. Padmanabhan T, Kamaraj V, Magwood L, Starly B. Experimental investigation on the operating variables of a near-field electrospinning process via response surface methodology. J Manuf Process. 2011;13:104-12.

7. Taylor GI. Electrically driven jets. Proc R Soc London Ser A. 1969;313:453-75
8. Reneker DH, Yarin AL, Zussman E, Xu H. Electrospinning of nanofibers from polymer solutions and melts. Adv Appl Mech. 2007;41:43-195.

9. Portela, P.M.D., Rocha, J.G.V., Méndez, S.L. Montagem e automatização de um sistema de electrospinning [dissertação]. Braga, Portugal: Escola de Engenharia, Departamento de Eletronica Industrial, Universidade do Minho; 2010. 148 p.

10. Bisht GS, Canton G, Mirsepassi A, Kulinsky L, Oh S, DunnRankin D, et al. Controlled continuous patterning of polymeric nanofibers on three-dimensional substrates using low-voltage near-field electrospinning. Nano Lett. 2011;11:1831-7.

11. Ru, C., Chen, J., Shao, Z., Pang, M., Luo, J. A novel mathematical model for controllable near-field electrospinning. AIP Advances. 2014;4(1): 017108-1-017108-11.

12. Zheng G, Li W, Wang X, Wu D, Sun D, Lin L. Precision deposition of a nanofibre by near-field electrospinning. J Phys D Appl Phys. 2010;43: 415501.

13. Vatankhah E, Semnani D, Prabhakaran MP, Tadayon M, Razavi S, Ramakrishna S. Artificial neural network for modeling the elastic modulus of electrospun polycaprolactone/gelatin scaffolds. Acta Biomater. 2014;10:709-21.

14. $\mathrm{MaZ}, \mathrm{Ph} \mathrm{D}$, Kotaki M, Ph D, Inai R. Potential of nanofiber matrix as tissue-engineering scaffolds. Tissue Eng. 2005;11:101-09.

15. Park JB. Biomaterials: An introduction. New York: Plenum; 1979.

16. Hench LL, Ethridge E. Biomaterials: an interfacial approach. New York: Academic Press; 1982.

17. Hutmacher DW. Scaffolds in tissue engineering bone and cartilage. Biomaterials. 2000;21:2529-43.

18. Wise DL, Trantolo DJ, Altobelli DE, Yaszemski MJ, Gresser JD, editors. Human biomaterials applications. Totowa, New Jersey: Humana Press; 1996.

19. Macedo JLS, Rosa SC, Macedo KCS, Castro C. Fatores de risco da sepse em pacientes queimados. Rev Col Bras Cir. 2005;32(4):173-77.

20. Macedo JLS, Santos JB. Infectious complications in burn patients. Rev Soc Bras Cir Plást. 2006;21(2):108-11.

21. Tian H, Tang Z, Zhuang X, Chen X, Jing X. Biodegradable synthetic polymers: Preparation, functionalization and biomedical application. Progress in Polymer Science. 2012;37:237-80.

22. Li Y, Lim CT, Kotaki M. Study on structural and mechanical properties of porous PLA nanofibers electrospun by channelbased electrospinning system. Polymer. 2015;56:572-80.

23. Liu Z, Li X, Yang Y, Zhang K, Wang X, Zhu M, et al. Control of structure and morphology of highly aligned PLLA ultrafine fibers via linear-jet electrospinning. Polymer (Guildf). 2013;54:6045-51.

24. Savioli Lopes M, Jardini AL, Maciel Filho R. Poly (lactic acid) production for tissue engineering applications. Procedia Eng. 2012;42:1402-13.

25. Lasprilla AJR, Martinez GAR, Lunelli BH, Jardini AL, Filho RM. Poly-lactic acid synthesis for application in biomedical devices - A review. Biotechnol Adv. 2012;30:321-8.

26. Perea GNR. Eletrofiação de Nanocompósito de Poli (L-Ácido Lático) com Hidroxiapatita para Regeneração Óssea [dissertação]. Campinas (SP): Universidade Estadual de Campinas, Faculdade de Engenharia Mecânica; 2011. 42 p.

27. Furth ME, Atala A, Van Dyke ME. Smart biomaterials design for tissue engineering and regenerative medicine. Biomaterials. 2007;28:5068-73.

28. Duarte MAT. Influencia da concentração de PCL-T em membranas de PLDLA: estudo in vitro e in vivo [tese]. Campinas (SP): Universidade Estadual de Campinas, Faculdade de Engenharia Mecânica; 2009. 135 p.

29. Ero-Phillips O, Jenkins M, Stamboulis A. Tailoring crystallinity of electrospun Plla Fibres by control of electrospinning parameters. Polymers (Basel). 2012;4:1331-48.

30. Enayati MS, Behzad T, Sajkiewicz P, Bagheri R, GhasemiMobarakeh L, Łojkowski W, et al. Crystallinity study of electrospun poly (vinyl alcohol) nanofibers: Effect of electrospinning, filler incorporation, and heat treatment. Iran Polym J. 2016;25:647-59. 
31. Lin T, Wang H, Wang H, Wang X. The charge effect of cationic surfactants on the elimination of fibre beads in the electrospinning of polystyrene. Nanotechnology. 2004;15:1375-81.

32. Millás ALG. Instalação da tecnologia de electrospinning para a produção e caracterização de nanofibras de celulose incorporadas com óleos naturais [dissertação]. Campinas (SP): Universidade Estadual de Campinas, Faculdade de Engenharia Mecânica 2012.

33. Pezzin SH, Olalla ÁS, Torres EG, Santos AL, Duarte MAT, Silva $\mathrm{L}$, et al. Preparation of PHB membranes by electrospinning and characterization for tissue engineering applications. Materia (Rio J.). 2018;23(4).

34. Costa RGF, De Oliveira JE, De Paula GF, De Picciani PHS, De Medeiros ES, Ribeiro C, et al. Eletrofiação de polímeros em solução. Parte I: fundamentação teórica. Polímeros. 2012;22:170-7.

35. Lannutti J, Reneker D, Ma T, Tomasko D, Farson D. Electrospinning for tissue engineering scaffolds. Mater Sci Eng C. 2007;27:504-9. 